\title{
EFL Students' Perceptions Of Online Learning During The Covid- 19 Pandemic: A Case Study
}

\author{
Dorinë Rakaj ${ }^{*}$ \\ 'University of Prizren "Ukshin Hoti", Prizren, Kosovo \\ 1*dorine.rakaj@uni-prizren.com
}

\begin{tabular}{|c|c|}
\hline Article Info & ABSTRACT \\
\hline $\begin{array}{l}\text { Article history } \\
\text { Received August 8, } 2021 \\
\text { Revised October 6, 2021 } \\
\text { Accepted November 2, } 2021\end{array}$ & $\begin{array}{l}\text { The COVID-19 pandemic has drastically changed many } \\
\text { things, including education. This study aimed to examine } \\
\text { students' perceptions of online learning during the COVID-19 } \\
\text { pandemic. The study employed a quantitative approach. }\end{array}$ \\
\hline $\begin{array}{l}\text { Keywords: COVID-19 } \\
\text { pandemic; Online classes; } \\
\text { Kosovo; Perceptions, University } \\
\text { students }\end{array}$ & $\begin{array}{l}\text { questionnaire to } 100 \text { selected undergraduate students } \\
\text { majoring in English Language and Literature at the University } \\
\text { of Prizren, Kosovo. The study's findings indicated that students } \\
\text { had negative perceptions of online classes during the COVID- } \\
19 \text { pandemic. Lack of quality, lack of proper interaction and } \\
\text { concentration, lack of computer skills were the major problems } \\
\text { experienced by undergraduate students at the University of } \\
\text { Prizren. Based on the research results, it can be concluded that } \\
\text { the respondents of this study were not willing to accept their } \\
\text { courses via online mode. }\end{array}$ \\
\hline
\end{tabular}

\section{INTRODUCTION}

The COVID-19 pandemic has changed the education system worldwide (Huda, Wahyuni, \& Fauziyah, 2021). Online learning has emerged as a solution to this problem. Many higher education institutions (HEls) worldwide have entirely shifted to online teaching to keep learning on its track. This transition has created challenges for both teachers and students. The COVID-19 pandemic has forced teachers and students to study and learn from their homes. Most teachers and students were caught unprepared because they did not have any previous online teaching or learning experience. According to Xhaferi and Xhaferi (2020, p.88), teachers and students "were forced to start using Zoom service which allows up to 100 participants in meetings for free". Some universities, including the University of Prizren, have used a hybrid approach to learning and teaching through different learning platforms such as Zoom, Moodle, Google Meet, Google Classroom, etc. Online teaching is a new model for Kosovar teachers; it has not previously been part of regular classes due to technological infrastructure. It is hoped that this study will help university authorities design practical and valuable online learning for students in case of emergencies. This study aimed to answer the following research questions:

RQ1: What are EFL students' perceptions of the online vs. classroom mode during the COVID19 pandemic? 
RQ2: What are EFL students' perceptions of personal factors in online classes during the COVID19 pandemic?

\section{LITERATURE REVIEW}

Recent studies have investigated students' perceptions of online learning during the COVID-19 pandemic (Abbasi et al., 2020; Adnan \& Anwar, 2020; Agarwal \& Kaushik, 2020; Demuyakor, 2020; Nambiar, 2020; Xhelili et al., 2021).

Abbasi et al. (2020) examined students' perceptions of e-learning. They collected data from 382 students using a 5-point Likert scale. The results indicated that participants (77.4\%) had negative perceptions of e-learning. Moreover, the researchers concluded that students did not prefer e-teaching.

Adnan and Anwar (2020) examined the attitudes of Pakistani higher education students toward online learning. The study's findings showed that undergraduate and graduate students had reservations about online learning. In addition, many students were unable to access the Internet due to technical and financial issues. A similar study was conducted by Nambiar (2020). He surveyed students' perceptions and experiences related to online classes. A total of 407 students participated in the study. The study results indicated that students perceived face-to-face learning more positively than did online learning. Similarly, in a study conducted in China by $\mathrm{Ng}$ et al. (2020), out of 20 students who responded, 17 students preferred face-to-face classroom lessons compared to remote learning. Only one student felt more at the ease of having online lessons, while two students did not.

Xhelili et al. (2021) conducted a study with 627 college students to analyze their perceptions and challenges during online learning due to the pandemic. The results showed that students had a more positive attitude toward the classroom learning environment. On the other hand, Agarwal and Kaushik (2020) obtained data from 77 participants about their perceptions at the end of the lecture series. The results showed that participants (97\%) found the sessions exciting and enjoyable. Moreover, they perceived that the sessions were tailored to their level of learning. The researchers suggested that online classes should be part of the postgraduate curriculum in India when the COVID-19 pandemic is over.

Similarly, Demuyakor (2020) examined Ghanaian international students' level of satisfaction with online learning in higher educational institutions in Beijing, China. The findings showed that students supported the implementation of online learning programs. However, the results showed that students spent much money buying Internet data for online learning. Furthermore, another study showed that students had a positive perception of using online learning platforms (Bagata, Umama, \& Fikri, 2020). Although several studies have investigated online learning and teaching during the COVID-19 pandemic, little attention has been paid to analyzing students' perceptions of online learning in Kosovo, significantly higher education. 


\section{METHODS}

A quantitative approach was used in the present study. The researcher developed a questionnaire based on Nambiar's (2020) research work. The questionnaire with 16 closedended questions was distributed to students through Google Forms. The questionnaire assessed two dimensions: a) online vs. classroom mode and b) personal factors during online classes.

A total of $100 \mathrm{EFL}$ students majoring in English Language and Literature participated in this study. Students were asked to rate their perceptions of online learning using a Likert scale ("Agree" to "Disagree"). The researcher collected the questionnaires at the end of the summer semester of the 2020/2021 academic year. Students' responses were tabulated and converted to percentages to present their overall perceptions.

\section{RESULTS}

Table 1 shows the results collected from $100 \mathrm{EFL}$ students majoring in English Language and Literature at Prizren.

Table 1. Students' perception of online classes- Questionnaire results

\begin{tabular}{lll}
\hline 1. Online classes are more effective than classroom & Agree & $7 \%$ \\
& Neutral & $26 \%$ \\
2. There is a lack of interaction during online classes & Disagree & $67 \%$ \\
& Agree & $51.5 \%$ \\
3. Online classes are more convenient than the classroom method & Neutral & $29.3 \%$ \\
& Disagree & $19.2 \%$ \\
& Agree & $20 \%$ \\
4. Quality of discussion is low in online classes & Neutral & $22 \%$ \\
& Disagree & $58 \%$ \\
& Agree & $69 \%$ \\
5. Learning and knowledge transfer happens more in online & Neutral & $17 \%$ \\
classes & Disagree & $14 \%$ \\
& Agree & $12 \%$ \\
6. Online classes are less structured than classroom mode & Neutral & $35 \%$ \\
& Disagree & $53 \%$ \\
7. Online classes save time & Agree & $40.4 \%$ \\
& Neutral & $41.4 \%$ \\
8. Technical issues disrupt the flow and pace of online classes & Disagree & $18.2 \%$ \\
& Agree & $52 \%$ \\
& Neutral & $24 \%$ \\
9. It is difficult to clarify doubts in online classes compared to & Disagree & $24 \%$ \\
classroom mode & Agree & $88.9 \%$ \\
& Neutral & $11.1 \%$ \\
\hline
\end{tabular}

As shown in Table 1, $67 \%$ of students disagreed that online classes were more effective than the classroom, $7 \%$ agreed, and $26 \%$ were neutral. In examining the second item, $51.5 \%$ 
reported a lack of interaction during online classes, while $29.3 \%$ were neutral. 58\% disagreed that online classes were more convenient than classroom methods. About $69 \%$ of students agreed that the quality of discussion was low in online classes, whereas $53 \%$ disagreed that learning and knowledge transfer occurred more in online classes. Moreover, there was a slight difference for item 6. About $40.4 \%$ of the students agreed that online classes were less structured than the classroom mode, and $41.4 \%$ were neutral.

Moreover, $52 \%$ of them agreed with item 7 about saving time. A high percentage of students (88.9\%) agreed that technical issues disrupted the flow and pace of online classes. Additionally, $68.7 \%$ of students agreed that clarifying doubts in online classes was more challenging than in the classroom mode, while $7.1 \%$ disagreed with this item.

Table 2. Students' perception of online classes- Questionnaire results

\begin{tabular}{|c|c|c|}
\hline 10. Lack of computer skills makes uncomfortable during online classes & $\begin{array}{l}\text { Agree } \\
\text { Neutral } \\
\text { Disagree }\end{array}$ & $\begin{array}{l}36 \% \\
29 \% \\
35 \%\end{array}$ \\
\hline $\begin{array}{l}11 . \text { I feel more comfortable participating in online class discussions } \\
\text { compared to classroom }\end{array}$ & $\begin{array}{l}\text { Agree } \\
\text { Neutral } \\
\text { Disagree }\end{array}$ & $\begin{array}{r}29 \% \\
30 \% \\
41 \%\end{array}$ \\
\hline 12. I find it difficult to understand and follow online classes & $\begin{array}{l}\text { Agree } \\
33.3 \% \\
\text { Neutral } \\
40.4 \% \\
\text { Disagree } \\
26.3 \%\end{array}$ & \\
\hline 13. I feel less anxious in online classes & $\begin{array}{l}\text { Agree } \\
\text { Neutral } \\
\text { Disagree }\end{array}$ & $\begin{array}{r}42 \% \\
36 \% \\
22 \%\end{array}$ \\
\hline $\begin{array}{l}\text { 14. I get easily distracted and have difficulty concentrating during } \\
\text { online classes }\end{array}$ & $\begin{array}{l}\text { Agree } \\
64.6 \% \\
\text { Neutral } \\
22.2 \% \\
\text { Disagree } \\
13.1 \%\end{array}$ & \\
\hline 15. I feel lazy and disinterested during online classes & $\begin{array}{l}\text { Agree } \\
\text { Neutral } \\
\text { Disagree }\end{array}$ & $\begin{array}{l}52 \% \\
23 \% \\
25 \%\end{array}$ \\
\hline 16. I do not feel motivated to participate in online class discussions & $\begin{array}{l}\text { Agree } \\
39.4 \% \\
\text { Neutral } \\
\text { Disagree } \\
32.3 \%\end{array}$ & $28.3 \%$ \\
\hline
\end{tabular}

The results presented in Table 2 show that $36 \%$ of students agreed that the lack of computer skills made them uncomfortable during online classes, $35 \%$ disagreed, and $29 \%$ were neutral. About $41 \%$ of students disagreed that they felt more comfortable participating in online class discussions compared to the classroom, $30 \%$ were neutral, and $29 \%$ agreed with 
this item. About $40.4 \%$ of students were neutral about understanding online classes, $33.3 \%$ agreed, and $26.3 \%$ disagreed. $42 \%$ of students agreed that they felt less anxious in online classes, $36 \%$ were neutral, and $22 \%$ disagreed with this item. The vast majority of students $(64.6 \%)$ agreed that they were easily distracted and had difficulty concentrating during online classes; $13.1 \%$ disagreed, $22.2 \%$ were neutral. Additionally, $52 \%$ of them agreed that they felt lazy and disinterested during online classes, $25 \%$ disagreed, and $23 \%$ were neutral. Regarding the last item, $39.4 \%$ of students agreed that they did not feel motivated to participate in online class discussions, $32.3 \%$ disagreed, and $28.3 \%$ were neutral.

\section{DISCUSSION}

Generally speaking, the study results revealed that students had negative perceptions of online classes. Regarding the first research question, "What are EFL students' perceptions of the online vs. classroom mode during the COVID-19 pandemic?" students' answers supported the results of previous studies that students preferred in-class learning to online learning (Abbasi et al., 2020; Adnan \& Anwar, 2020; Nugroho et al., 2020; Nambiar, 2020; Xhelili et al., 2021). They did not perceive online and face-to-face classes as equivalent (Platt, Raile, \& Yu, 2014). This perception might be attributed to the fact that most participants were not familiar with online learning/teaching. Interestingly, this finding is different from the findings of Agarwal and Kaushik (2020) and Demuyakor (2020). For example, Demuyakor (2020) highlighted that Ghanaian students enrolled in online courses in China perceived online learning as effective. Regarding the second research question, "What are EFL students' perceptions of personal factors in online classes during the COVID-19 pandemic?" according to the questionnaire results, students faced many obstacles such as lack of computer skills (36\%), lack of concentration (64.6\%), technical issues (88.9\%), and less motivation (39.4\%). Universities should train both teachers and students in specific technologies to avoid these obstacles. Universities should also train teachers not to pressure students, but they should give them full support (Mahmood, 2020). Furthermore, teachers should prepare lesson materials for less than 30 minutes if they want their students to be attentive and focused on online classes (Mahmood, 2020).

It should be noted that even though EFL students' perceptions of online learning tend to be negative, the study found some positive attitudes regarding online classes. For example, participants perceived online learning as more convenient in saving time than face-to-face learning in the classroom. Moreover, the findings showed that they felt less anxious during online classes. In summary, the results of this study showed that online learning was less for students than face-to-face learning (Azhari, 2021). 


\section{CONCLUSION}

This study aimed to examine EFL students' perceptions of online learning during the COVID-19 pandemic at the University of Prizren. This study showed that students preferred inclass learning to online learning. Lack of quality, lack of proper interaction and concentration, and lack of computer skills were the major problems experienced by EFL students during the COVID-19 pandemic. Even though online classes were reported to be less structured, the respondents of this study perceived online learning as more convenient for saving time than face-to-face learning in the classroom. It can be concluded that they were not willing to accept their courses online.

\section{LIMITATIONS}

In this study, the researcher addressed students' perceptions of online learning during the COVID-19 pandemic at the University of Prizren. Therefore, the results of this study cannot be generalized to students at other universities in Kosovo. Although the sample size is small, the data can shed light on the issues mentioned above faced by EFL students during the COVID19 pandemic.

\section{FUTURE RESEARCH}

For future research, the researcher suggests an investigation of students' perceptions of online learning from other universities in Kosovo. Moreover, other researchers could analyze teachers' perceptions of the online teaching model. The opinion of both would provide guidance and recommendations to policymakers and higher education institutions (HEIs) regarding online learning/teaching.

\section{ACKNOWLEDGMENT}

The researcher would like to thank all the students who contributed to this research.

\section{REFERENCES}

Abbasi, S., Ayoob, T., Malik, A., \& Memon, S. I. (2020). Students' Perceptions regarding E-learning during COVID-19 at a private medical college Pakistan Journal of Medical Sciences, 36(COVID19-S4), 57-61.

Adnan, M. \& Anwar, K. (2020). Online learning amid the COVID-19 pandemic: Students' perspectives. Journal of Pedagogical Research, 1 (2), 45-51.

Agarwal, S., \& Kaushik, J. S. (2020). Student's perception of online learning during COVID Pandemic. The Indian Journal of Pediatrics.

Azhari, T. (2021). Students' perception on online learning during the Covid-19 pandemic: A case study of Universitas Malikussaleh students. Proceedings of the International 
Conference on Social Science, Political Science, and Humanities (ICOSPOLHUM 2020). Atlantis Press.

Bagata, D. T., Umama, A., \& Fikri, D. (2020). EFL university student's perception of the use of online learning platform in the COVID 19 pandemic . Jurnal Penelitian, Pendidikan, dan Pembelajaran, 15(34).

Demuyakor, J. (2020). Coronavirus (COVID-19) and online learning in higher institutions of education: A survey of the perceptions of Ghanaian international students in China. Online Journal of Communication and Media Technologies, 10(3), e202018. https://doi.org/10.29333/ojcmt/8286

Huda, N., Wahyuni, T. S., \& Fauziyah, F. D. (2021). Students' perceptions of online mathematics learning and its relationship towards their achievement. Advances in Social Science, Education and Humanities Research, Atlantis Press, 522-529.

Mahmood, S. (2020). Instructional strategies for online teaching in COVID-19 pandemic. Human Behaviour and Emerging Technologies in press.

Nambiar, D. (2020). The impact of online learning during COVID-19: students' and teachers' perspectives. International Journal of Indian Psychology, 8(2), 783-793.

Ng, C. D., Mahmoud, S., Hald, E., \& Fang, Q. (2020). The challenges in teaching calculus remotely during the COVID-19 pandemic. Research Square. Retrieved from https://doi.org/10.21203/rs.3.rs-43728/v1

Platt, C. A., Raile, A. N., \& Yu, N. (2014). Virtually the same?: Student perceptions of the equivalence of online classes to face-to-face classes. MERLOT Journal of Online Learning and Teaching. 10(3), 489-503.

XHAFERI, B., \& XHAFERI, G. (2020). ONLINE LEARNING BENEFITS AND CHALLENGES DURING THE COVID 19 - PANDEMIC- STUDENTS' PERSPECTIVE FROM SEEU. SEEU REVIEW, 15 (1), 86-103.

Xhelili, P., Ibrahimi, E., Rruci, E., \& Sheme, K. (2021). Adaptation and perception of online learning during the COVID-19 pandemic in Albanian university students. International Journal on Studies in Education (IJonSE), 3(2), 103-111. 